\title{
PENGARUH PELATIHAN DAN KOMPENSASI TERHADAP KINERJA KARYAWAN PADA PT. G4S SECURITY SERVICE JAKARTA (Studi Kasus Pada Karyawan Security Projek PT HM Sampoerna Tbk Di Jakarta)
}

\author{
Muhammad Luffi ${ }^{1}$, Agrasadya ${ }^{2}$, Muger Apriansyah ${ }^{3}$ \\ Fakultas Ekonomi, Universitas Pamulang \\ Email: dosen01866@unpam.ac.id
}

\begin{abstract}
Purpose This purpose of this study was to determine the effect of training and compensation on employee performance at PT G4s Security Service Jakarta, (case study on security project employees of PT HM Sampoerna Tbk in Jakarta).

Methods. The research methode used in this reseach is descriptive research with quantitative data analysis, meaning that this research is limited to expressing a problem and trying to find a solution or solution to an existing problems. The data used in this study is a survey methode through questionnaire techniques, and observation. The sample in this study used a saturated sample, namely taking all members of the population as respondents wtih the number of employees at PT G4s Security Service Jakarta who work in the PT HM Sampoerna Tbk projet, totaling 78 people. The data analysis used validity test, reliability, classical assumption test (normality test, multicollinearitay test, heteroscedasticity test, auto correlation), linier regression test, correlation coefficient test, determination coefficient test and hypothesis test.
\end{abstract}

Findings. The results of this study indicate multiple linear regression equation $Y=9,866+$ $0,290 X 1+0,472 X 2$, meaning that even without the influence of training variables (X1) and compensation $\left(X_{2}\right)$ variables, employees still have an empolyee performance level of 9,866. $R$ Correlation (correlation coefficient) of 0,713 means that this indicates that there is a very strong relationship with employee performance. The coefficient of determination of the value of $R 2$ ( $R$ square) of 0,509 means that this 50,9\% the effect of training and compensation simultaneosly contributes to employee performance the remaining $49,1 \%$ is influenced by other factors. This is evidenced by the partial and simultaneous $T$ test, the effect of training $\left(X_{1}\right)$ on $(Y)$ with the result of $t$ tcount $>t$ table $(5,276>1,992)$ and compensation $(X 2)$ to $(Y)$ with $t$ count $>t$ table $(7,340>1,992)$, and also strengthened by the $p$ value $<\operatorname{sig} 0,05(0,000<0,05)$ and the result of the $F$ test (simultaneous) obtained the $F$ count $>$ F table $(38,874>2,73)$, thus then $\mathrm{HO1}$ is rejected and HO3 is accepted, so it can be concluded that simultaneously there is a positive and significant influence between training and compensation on employee performance.

Implication. Training, compensation, and employee performance are variables that are the objects of research taken by the author and the findings show that training, compensation together or simultaneously have a positive and significant effect on employee performance. Therefore, companies are expected to pay more attention to the factors of providing training and providing appropriate compensation in order to improve employee performance in the future.

Keywords. Training, Compensation, Employee Performance 


\begin{abstract}
ABSTRAK
Tujuan. Untuk mengetahui Pengaruh Pelatihan dan Kompensasi Terhadap Kinerja Karyawan pada PT G4s Security Service Jakarta, (Studi Kasus Pada Karyawan Security Projek PT HM Sampoerna Tbk Di Jakarta).

Metode. Metode penelitian yang dipergunakan dalam penelitian adalah penelitian deskriptif dengan analisis data kuantitatif, artinya penelitian ini hanya sebatas mengungkapkan suatu permasalahan dan mencoba menemukan solusi atau pemecahan dari suatu permasalahan yang ada. Data yang digunakan dalam penelitian ini adalah dengan metode penelitian survey dengan melalui teknik kuesioner, dan observasi. Sampel dalam penelitian ini menggunakan sampel jenuh yaitu mengambil seluruh anggota populasi sebagai responden dengan jumlah kayawan pada PT G4s Security Service Jakarta yang bekerja di projek PT HM Sampoerna Tbk yang berjumlah 78 orang. Analisis data menggunakan uji validitas, reliabilitas, uji asumsi klasik (uji normalitas, uji multikolinieritas, uji heteroskedastisitas, uji auto korelasi), uji Regresi linier ,uji koefisien korelasi, uji koefisien determinasi dan uji hipotesis.
\end{abstract}

Hasil. Hasil penelitian ini menunjukkan persamaan regresi linier berganda $Y=9,866+$ $0,290 \mathrm{X} 1+0,472 \mathrm{X} 2$ artinya meskipun tanpa ada pengaruh variabel pelatihan (X1) dan kompensasi (X2) maka karyawan tetap memiliki tingkat kinerja karyawan sebesar 9,866. Korelasi R (koefisien korelasi) sebesar 0,713 artinya hal ini menunjukkan bahwa terjadi hubungan yang sangat kuat terhadap kinerja karyawan. Koefisien determinasi nilai R2 (R squre) sebesar 0,509 artinya sebesar 50,9\% Pengaruh Pelatihan dan Kompensasi secara simultan memiliki kontribusi terhadap kinerja karyawan, sisanya sebesar $49,1 \%$ dipengaruhi oleh faktor lain. Hal ini dibuktikan dengan uji $\mathrm{T}$ secara parsial dan simultan, pengaruh pelatihan $(\mathrm{X} 1)$ terhadap $(\mathrm{Y})$ dengan hasil nilai $t$ hitung $>t$ tabel $(5,276>1,992)$ dan kompensasi $(\mathrm{X} 2)$ terhadap ( $\mathrm{Y}$ ) dengan nilai $\mathrm{t}$ hitung $>\mathrm{t}$ tabel $(7,340>1992)$, dan diperkuat juga dengan nilai $p$ value $<$ Sig 0,05 atau $(0,000<0,05)$, dan hasil uji $\mathrm{F}$ (simultan) diperoleh nilai $\mathrm{F}$ hitung $>\mathrm{F}$ tabel $(38,874>2,73)$, dengan demikian maka H01 ditolak dan H03 diterima sehingga dapat disimpulkan bahwa secara simultan terdapat pengaruh yang positif dan signifikan antara pelatihan dan kompensasi terhadap kinerja karyawan .

Implikasi. Pelatihan, kompensasi, dan kinerja karyawan adalah variabel yang menjadi obyek penelitian yang diambil penulis dan menghasilkan temuan ternyata pelatihan, kompensasi secara bersama-sama atau simultan berpengaruh positif dan signifikan terhadap kinerja karyawan. Oleh karena itu, perusahaan diharapkan agar lebih memperhatikan faktor pemberian pelatihan dan pemberian kompensasi yang sesuai agar dapat meningkatkan kinerja karyawan ke depan.

Kata Kunci. Pelatihan, Kompensasi, Kinerja Karyawan.

\title{
1. Pendahuluan
}

PT G4s Security Service adalah perusahaan keamanan global terkemuka yang terintegrasi, dengan spesialisasi dalam penyediaan layanan dan solusi keamanan untuk pelanggan. Misinya adalah untuk menciptakan nilai keuntungan yang berkelanjutan bagi para pelanggan dan pemegang saham dengan menjadi mitra penyedia jasa terbaik di seluruh pasar keamanan. Pada PT G4S Security Service Jakarta terdapat masalah internal dibagian Security Officer (SO), kinerja karyawan dalam devisi ini security officer kurang maksimal dalam melaksanakan atau menjalankan tugasnya dilapangan, sehingga ada beberapa klien atau pengguna jasa tersebut yang komplain atas performance dan pelayanan yang diberikan. Karena adanya security atau petugas yang belum mengerti tugas dasar atau pokok sebagai petugas keamanan dan ada beberapa sebagian yang belum mendapatkan pelatihan. Dengan ini 
data pelatihan karyawan atau security officer pada PT G4S Security Service Jakarta sebagai berikut:

Tabel 1. Data Pelatihan Karyawan Bagian Security Officer Tahun 2016-2019

\begin{tabular}{|c|c|c|c|c|c|}
\hline Tahun & $\begin{array}{c}\text { Jumlah } \\
\text { karyawan }\end{array}$ & $\begin{array}{c}\text { Karyawan } \\
\text { yang ikut } \\
\text { pelatihan }\end{array}$ & $\begin{array}{c}\text { Karyawan } \\
\text { yang } \\
\text { belum ikut } \\
\text { pelatihan }\end{array}$ & Realisasi & Target \\
\hline 2016 & 100 & 85 & 15 & $85 \%$ & $100 \%$ \\
\hline 2017 & 94 & 75 & 19 & $81 \%$ & $100 \%$ \\
\hline 2018 & 90 & 60 & 30 & $70 \%$ & $100 \%$ \\
\hline 2019 & 78 & 50 & 37 & $63 \%$ & $100 \%$ \\
\hline
\end{tabular}

Sumber : PT. G4S Security Service, 2019

Berdasarkan tabel diatas menunjukkan tidak semua karyawan atau security mengikuti pelatihan Gada Pratama, dilihat contoh pada tahun terahir yaitu tahun 2019 karyawan yang ikut pelatihan sebanyak 50 orang dan yang belum ikut pelatihan 37 orang atau yang sudah terealisasi baru 63\% dari target yang seharusnya 100\%. Pelatihan Gada pratama adalah pelatihan dasar wajib bagi calon anggota atau petugas security, pelatihan ini fungsinya untuk menyediakan layanan keamanan profesional untuk gedung-gedung, kantor publik, insfratruktur publik dan lokasi-lokasi bisnis. Hal tersebut menyebabkan tidak meratanya pengetahuan karyawan terkait dengan tugas pokok keamanan, serta performance dan bagaimana berkomunikasi yang baik dengan klien atau pengguna jasa.

Selain pelatihan yang dibutuhkan oleh sumber daya manusia untuk menunjang kinerjanya dalam suatu perusahaan, bukan menjadi hal yang asing apabila perusahaan memberikan kompensasi terhadap karyawan, pemberian kompensasi dari perusahaan dapat mempengaruhi kinerja secara keseluruhan. Pada perusahaan PT G4S Security Service Jakarta ini, masalah kompensasi merupakan suatu yang sangat penting dalam meningkatkan kinerja karyawan sehingga dibutuhkan suatu evaluasi karyawan yang dapat meningkatkan kecepatan dan ketepatan dalam hal melaksanakan tugas sebagai petugas keamanan. Dengan kompensasi yang baik dan adil, diharapkan dapat meningkatkan kinerja karyawan.

Tabel 2. Data Kompensasi Karyawan PT. G4S Security Service 2019

\begin{tabular}{|c|c|c|c|c|c|c|}
\hline No & Devisi & $\begin{array}{c}\text { Jumlah } \\
\text { karyawan }\end{array}$ & Gaji & $\begin{array}{c}\text { Bonus } \\
\text { atau } \\
\text { insentif }\end{array}$ & $\begin{array}{c}\text { Uang } \\
\text { Makan }\end{array}$ & Total \\
\hline 1 & Team Leader & 8 & 3.940 .000 & - & 560.000 & 4.500 .000 \\
\hline 2 & SO (Security Officer) & 70 & 3.940 .000 & - & 560.000 & 4.500 .000 \\
\hline
\end{tabular}

Sumber: PT G4S Security Service tahun, 2019

Berdasarkan table diatas dapat disimpulkan bahwa gaji untuk team leader dan SO atau security officer masih sama, dengan gaji sebesar 3.940 .000 sesuai dengan UMR Jakarta pada tahun 2019 dan ditambah dengan uang makan sebesar 560.000 dengan total menerima 4.500.000 sementara leader ini mempunyai tanggung jawab yang lebih banyak daripada SO, maka hasil yang di dapatkan leader ini sangat mempengaruhi kepada kinerja sebagai leader dari team SO tersebut. Dan juga insentif atau bonus di atas menunjukkan team leader dan SO tidak menerima sama sekali, ini juga sangat berpengaruh kepada kinerja dan akan menjadi kecemburuan sosial bagi leader dan SO tersebut. Karena kompensasi ini sangat memotivasi karyawan untuk melakukan kinerja yang lebih baik.

Kinerja seorang karyawan merupakan hal yang bersifat individual, karena setiap karyawan mempunyai tingkat kemampuan yang berbeda dalam mengerjakan tugasnya. Menurut Kasmir (2016:182), "kinerja merupakan hasil kerja dan perilaku kerja yang telah 
dicapai dalam menyelesaikan tugas-tugas dang tanggung jawab yang diberikan dalam suatu periode tertentu". Meningkatnya kinerja perorangan (individual performance) maka kemungkinan besar juga akan meningkatkan kinerja perusahaan (coorporate performance) karena keduanya mempunyai hubungan yang erat. Sedangkan menurut Edison (2016:190), "kinerja adalah hasil dari suatu proses yang mengacu dan diukur selama periode waktu tertentu berdasarkan ketentuan atau kesepakatan yang telah ditetapkan sebelumnya". Berdasarkan penilaian kinerja karyawan yang tersedia pada admin, persentase kinerja karyawan PT G4S Security Service Jakarta.

Tabel 3. Data pencapaian kinerja karyawan PT. G4S Security Service

\begin{tabular}{|c|l|c|c|}
\hline No & \multicolumn{1}{|c|}{ Aspek } & Target (\%) & Pencapaian (\%) \\
\hline 1 & Kualitas kerja & 15 & 11 \\
\hline 2 & Kuantitas kerja & 15 & 12 \\
\hline 3 & Pemahaman terhadap SOP & 10 & 8 \\
\hline 4 & Disiplin & 10 & 8 \\
\hline 5 & Tanggung jawab & 10 & 7 \\
\hline 6 & Motivasi & 5 & 4 \\
\hline 7 & Inisiatif & 5 & 4 \\
\hline 8 & Penyesuaian diri & 5 & 3 \\
\hline 9 & Kepemimpinan & 5 & 4 \\
\hline 10 & Pemecahan masalah & 5 & 4 \\
\hline 11 & Kerja sama & 10 & 8 \\
\hline 12 & Pengambilan keputusan & 5 & 5 \\
\hline \multicolumn{2}{|c|}{ Jumlah } & 100 & 78 \\
\hline \multicolumn{2}{|c|}{ Rata-rata } \\
\hline
\end{tabular}

Sumber: Admin PT G4S Security Service tahun, 2019

Berdasarkan uraian di atas maka penulis tertarik melakukan penelitian dengan judul

"Pengaruh Pelatihan dan Kompensasi Terhadap Kinerja Karyawan pada PT G4s Security Service Jakarta". (Studi Kasus Pada Karyawan Security Projek PT HM Smpoerna Tbk Di Jakarta)

\section{Kajian Pustaka}

Pelatihan. Menurut Mangkunegara (2011:3), "pelatihan adalah suatu proses pendidikan jangka pendek yang mempergunakan prosedur sistematis dan terorganisir dimana pegawai dan non manajerial mempelajari pengetahuan dan keterampilan teknis dalam tujuan terbatas". Menurut Widodo (2015:82), menyatakan bahwa "pelatihan merupakan serangkaian aktifitas individu dalam meningkatkan keahlian dan pengatahuan secara sistemastis sehingga mampu memiliki kinerja yang profesional di bidangnya". Sedangkan menurut Mangku prawira dan Hubeis (dalam Hamali, 2016:62) menyatakan bahwa "pelatihan bagi karyawan merupakan sebuah proses mengajarkan pengetahuan dan keahlian tertentu serta sikap agar karyawan semakin terampil dan mampu melaksanakan tanggung jawabnya dengan semakin baik, sesuai dengan standar kerja". Untuk itu latihan kerja diperlukan bukan saja sebagai pelengkap akan tetapi sekaligus untuk memberikan dasar-dasar pengetahuan."

Kompensasi. Menurut Hasibuan (2016:118), "kompensasi adalah semua pendapatan yang berbentuk uang, barang langsung atau tidak langsung yang diterima karyawan sebagai imbalan atas jasa yang diberikan kepada perusahaan". Pembentukan system kompensasi yang efektif merupakan bagian penting dari manajemen sumber daya manusia karena membantu menarik dan mempertahankan pekerjaan-pekerjaan yang berbakat. Selain itu system kompensasi perusahaan memiliki dampak terhadap kinerja strategis. Menurut Handoko (2014:155), "kompensasi adalah segala sesuatu yang diterima karyawan sebagai balas jasa 
untuk kerja mereka". Program-program kompensasi juga penting bagi perusahaan, karena mencerminkan upaya organisasi untuk mempertahankan sumber daya manusia.

Kinerja Karyawan. Menurut Kasmir (2016:182), "kinerja merupakan hasil kerja dan perilaku kerja yang telah dicapai dalam menyelesaikan tugas-tugas dang tanggung jawab yang diberikan dalam suatu periode tertentu". Meningkatnya kinerja perorangan (individual performance) maka kemungkinan besar juga akan meningkatkan kinerja perusahaan (coorporate performance) karena keduanya mempunyai hubungan yang erat. Sedangkan Menurut Marwansyah (2016:229), "kinerja adalah pencapaian atau prestasi seseorang berkenaan dengan tugas-tugas yang dibebankan kepadanya”.

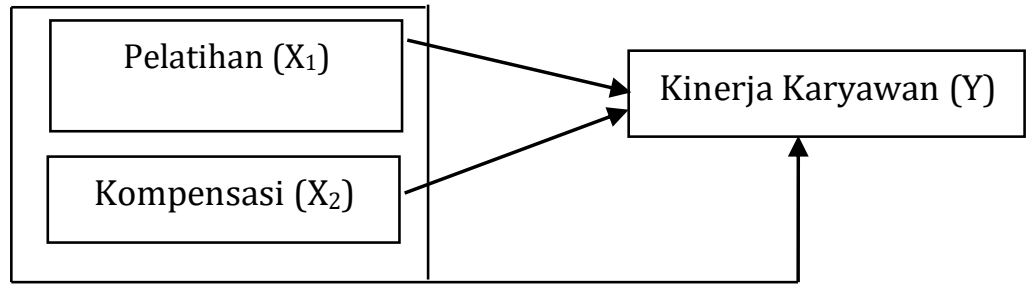

Gambar 1. Model Penelitian

\section{Hipotesis}

Ho1: Diduga tidak terdapat pengaruh positif dan signifikan pelatihan terhadap kinerja karyawan pada PT. G4S Security Service Jakarta

Ha1: Diduga terdapat pengaruh positif dan signifikan pelatihan terhadap kinerja karyawan pada PT. G4S Security Service Jakarta

Ho2 : Diduga tidak terdapat pengaruh positif dan signifikan kompensasi terhadap kinerja karyawan pada PT. G4S Security Service Jakarta

Ha2 : Diduga terdapat pengaruh positif dan signifikan kompensasi terhadap kinerja karyawan pada PT. G4S Security Service Jakarta

Ho3: Diduga tidak terdapat pengaruh positif dan signifikan pelatihan dan kompensasi terhadap kinerja karyawan pada PT. G4S Security Service Jakarta

Ha3 : Diduga terdapat pengaruh positif dan signifikan pelatihan dan kompensasi terhadap kinerja karyawan pada PT. G4S Security Service Jakarta

\section{Metode Penelitian}

Jenis penelitian dalam penelitian ini yaitu penelitian kuantitatif. Sedangkan metode yang digunakan dalam penelitian ini mengunakan metode asosiatif, menurut Sugiyono (2016:44), "yaitu Penelitian yang bertujuan untuk mengetahui pengaruh atau hubungan antara dua variabel atau lebih". Penelitian asosiatif mempunyai tingkatan yang lebih tinggi bila dibandingkan dengan deskriptif dan komparatif. Lebih lanjut Sugiyono (2016:44), "menjelaskan dengan penelitian asosiatif maka dapat dibangun suatu teori yang berfungsi untuk menjelaskan, meramalkan dan mengontrol suatu gejala".

Populasi dalam penelitian ini adalah seluruh karyawan PT G4S Security Service Jakarta yang berjumlah 78 orang. Sedangkan sampel data dalam penelitian adalah seluruh karyawan PT G4S Security Service Jakarta sebanyak 78 karyawan. Dalam penelitian ini Teknik yang digunakan penulis yaitu nonprobability sampling dengan menggunakan Teknik sampling jenuh. Menurut Sugiyono (2016:81), "teknik pengumpulan sampel bila semua anggota populasi digunakan sebagai sampel".

Teknik analisis data dengan menggunakan Uji validitas, uji reliabilitas, uji normalitas, uji multikolinearitas, uji heteroskedastisitas, uji regresi linier berganda, serta uji hipotesis. 
Tabel 3. Operasional Variabel Penelitian

\begin{tabular}{|c|c|c|c|}
\hline Variabel & Indikator & $\begin{array}{l}\text { Nomor } \\
\text { Kuesioner }\end{array}$ & Skala \\
\hline \multirow[t]{6}{*}{ Pelatihan $\left(\mathrm{X}_{1}\right)$} & 1. Tujuan & 1,2 & \multirow[t]{6}{*}{ Likert } \\
\hline & 2. Sasaran & 3,4 & \\
\hline & 3. Pelatih & 5,6 & \\
\hline & 4. Materi & 7 & \\
\hline & 5. Metode & 8,9 & \\
\hline & 6. Peserta Pelatihan & 10 & \\
\hline \multirow{4}{*}{ Kompensasi $\left(\mathrm{X}_{2}\right)$} & 1. Gaji atau Upah & 1,2 & \multirow{4}{*}{ Likert } \\
\hline & 2. Insentif & $3,4,5$ & \\
\hline & 3. Tunjangan & 6,7 & \\
\hline & 4. Fasilitas & $8,9,10$ & \\
\hline \multirow{6}{*}{$\begin{array}{c}\text { Kinerja Karyawan } \\
\text { (Y) }\end{array}$} & 1. Kualitas & 1,2 & \multirow[t]{6}{*}{ Likert } \\
\hline & 2. Kuantitas & 3,4 & \\
\hline & 3. Waktu & 5,6 & \\
\hline & 4. Penekanan Biaya & 7 & \\
\hline & 5. Pengawasan & 8,9 & \\
\hline & 6. Hubungan & 10 & \\
\hline
\end{tabular}

\section{Hasil Penelitian dan Pembahasan Uji Validitas}

Tabel 4. Hasil Uji Validitas

\begin{tabular}{|c|c|c|c|c|}
\hline No & Pernyataan & rhitung & rtabel & $\begin{array}{c}\text { Keterangan } \\
\text { Butir }\end{array}$ \\
\hline Pelatihan \\
\hline 1 & Butir Pernyataan 1 & 0,397 & 0,2227 & Valid \\
\hline 2 & Butir Pernyataan 2 & 0,501 & 0,2227 & Valid \\
\hline 3 & Butir Pernyataan 3 & 0,333 & 0,2227 & Valid \\
\hline 4 & Butir Pernyataan 4 & 0,526 & 0,2227 & Valid \\
\hline 5 & Butir Pernyataan 5 & 0,652 & 0,2227 & Valid \\
\hline 6 & Butir Pernyataan 6 & 0,484 & 0,2227 & Valid \\
\hline 7 & Butir Pernyataan 7 & 0,707 & 0,2227 & Valid \\
\hline 8 & Butir Pernyataan 8 & 0,689 & 0,2227 & Valid \\
\hline 9 & Butir Pernyataan 9 & 0,631 & 0,2227 & Valid \\
\hline 10 & Butir Pernyataan 10 & 0,465 & 0,2227 & Valid \\
\hline Kompensasi & & & \\
\hline 1 & Butir Pernyataan 1 & 0,545 & 0,2227 & Valid \\
\hline 2 & Butir Pernyataan 2 & 0,559 & 0,2227 & Valid \\
\hline 3 & Butir Pernyataan 3 & 0,380 & 0,2227 & Valid \\
\hline 4 & Butir Pernyataan 4 & 0,533 & 0,2227 & Valid \\
\hline 5 & Butir Pernyataan 5 & 0,545 & 0,2227 & Valid \\
\hline 6 & Butir Pernyataan 6 & 0,344 & 0,2227 & Valid \\
\hline 7 & Butir Pernyataan 7 & 0,643 & 0,2227 & Valid \\
\hline 8 & Butir Pernyataan 8 & 0,552 & 0,2227 & Valid \\
\hline 9 & Butir Pernyataan 9 & 0,671 & 0,2227 & Valid \\
\hline 10 & Butir Pernyataan 10 & 0,564 & 0,2227 & Valid \\
\hline
\end{tabular}




\begin{tabular}{|c|c|c|c|c|}
\hline No & Pernyataan & rhitung & rtabel & $\begin{array}{c}\text { Keterangan } \\
\text { Butir }\end{array}$ \\
\hline \multicolumn{4}{|l|}{ Kinerja Karyawan } \\
\hline 1 & Butir Pernyataan 1 & 0,423 & 0,2227 & Valid \\
\hline 2 & Butir Pernyataan 2 & 0,530 & 0,2227 & Valid \\
\hline 3 & Butir Pernyataan 3 & 0,472 & 0,2227 & Valid \\
\hline 4 & Butir Pernyataan 4 & 0,464 & 0,2227 & Valid \\
\hline 5 & Butir Pernyataan 5 & 0,483 & 0,2227 & Valid \\
\hline 6 & Butir Pernyataan 6 & 0,240 & 0,2227 & Valid \\
\hline 7 & Butir Pernyataan 7 & 0,743 & 0,2227 & Valid \\
\hline 8 & Butir Pernyataan 8 & 0,552 & 0,2227 & Valid \\
\hline 9 & Butir Pernyataan 9 & 0,581 & 0,2227 & Valid \\
\hline 10 & Butir Pernyataan 10 & 0,534 & 0,2227 & Valid \\
\hline
\end{tabular}

Sumber : Data diolah (2020)

Berdasarkan data tabel diatas, variabel kinerja karyawan $(\mathrm{Y})$ diperoleh nilai $r$ hitung > $r$ tabel $(0,2227)$, dengan demikian maka semua item kuesioner dinyatakan valid, untuk itu kuesioner yang digunakan layak untuk diolah sebagai data penelitian.

\section{Uji Reliabilitas}

Tabel 5. Hasil Uji Reliabilitas

\begin{tabular}{|c|c|c|}
\hline Variabel & Cronchbach's Alpha & Keterangan \\
\hline Pelatihan & 0,729 & Reliabilitas \\
\hline Kompensasi & 0,720 & Reliabilitas \\
\hline Kinerja Karyawan & 0,673 & Reliabilitas \\
\hline
\end{tabular}

Sumber : Data diolah (2020)

Berdasarkan pengujian pada tabel diatas, menunjukkan bahwa variabel Pelatihan $\left(\mathrm{X}_{1}\right)$, Kompensasi $\left(\mathrm{X}_{2}\right)$ dan Kinerja karyawan $(\mathrm{Y})$ dinyatakan reliabel, hal itu dibuktikan dengan masing-masing variabel memiliki nilai Cronbatch Alpha lebih besar dari 0,600.

\section{Uji Normalitas}

Tabel 6. Hasil Uji Normalitas

\begin{tabular}{|l|c|c|c|c|c|c|}
\hline \multicolumn{1}{|c|}{ Tests of Normality } \\
\hline & \multicolumn{3}{|c|}{ Kolmogorov-Smirnova } & \multicolumn{3}{|c|}{ Shapiro-Wilk } \\
\cline { 2 - 7 } & Statistic & df & Sig. & Statistic & df & Sig. \\
\hline Kinerja Karyawan (Y) & .097 & 78 & .065 & .981 & 78 & .283 \\
\hline
\end{tabular}

Sumber : Data diolah (2020)

Berdasarkan hasil pengujian pada tabel di atas, diperoleh nilai signifikansi $\alpha=$ 0,065 dimana nilai tersebut lebih besar dari nilai $\alpha=0,050$ atau $(0,065>0,050)$. Dengan demikian maka asumsi distribusi persamaan pada uji ini adalah normal.

\section{Uji Multikolinearitas}

Tabel 7. Uji multikolinearitas

Coefficients ${ }^{\mathbf{a}}$

\begin{tabular}{|c|l|r|r|}
\hline \multirow{2}{*}{ Model } & \multicolumn{2}{|c|}{ Collinearity Statistics } \\
\cline { 3 - 4 } \multicolumn{2}{|c|}{} & Tolerance & VIF \\
\hline \multirow{2}{*}{} & Pelatihan & .871 & 1.148 \\
\cline { 2 - 4 } & Kompensasi & .871 & 1.148 \\
\hline
\end{tabular}

a. Dependent Variable: Kinerja Karyawan

Sumber : Data diolah (2020) 
Berdasarkan hasil pengujian multikolinieritas pada tabel di atas diperoleh nilai tolerance masing-masing variabel bebas yaitu Pelatihan sebesar 0,871 dan Kompensasi sebesar 0,871, dimana kedua nilai tersebut kurang dari 1, dan nilai Variance Inflation Factor (VIF) variabel Pelatihan sebesar 1,148 serta Kompensasi sebesar 1,148 dimana nilai tersebut kurang dari 10. Dengan demikian model regresi ini tidak ada multikolinieritas.

\section{Uji Autokorelasi}

Tabel 8. Uji Autokorelasi

Model Summaryb

\begin{tabular}{|c|c|c|c|c|c|}
\hline Model & $\mathrm{R}$ & $\begin{array}{c}\mathrm{R} \\
\text { Square }\end{array}$ & $\begin{array}{c}\text { Adjusted R } \\
\text { Square }\end{array}$ & $\begin{array}{c}\text { Std. Error of } \\
\text { the Estimate }\end{array}$ & $\begin{array}{c}\text { Durbin- } \\
\text { Watson }\end{array}$ \\
\hline 1 & $.713^{\mathrm{a}}$ & .509 & .496 & 2.396 & 2.052 \\
\hline
\end{tabular}

a. Predictors: (Constant), Kompensasi, Pelatihan

b. Dependent Variable: Kinerja Karyawan

Sumber : Data diolah (2020)

Berdasarkan hasil pengujian pada tabel di atas, model regresi ini tidak ada autokorelasi, hal ini dibuktikan dengan nilai Durbin-Watson sebesar 2.052 yang berada diantara interval $1.550-2.460$.

\section{Uji Heteroskedastisitas}

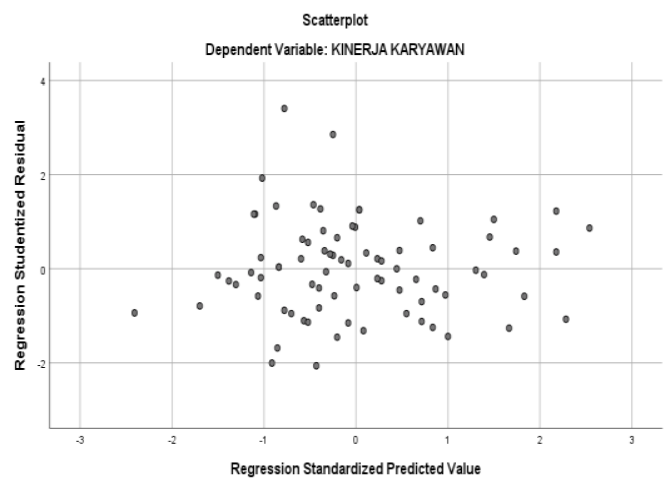

Gambar 2. Heteroskedastisitas

Berdasarkan hasil gambar di atas, titik-titik pada grafik scatterplot tidak mempunyai pola penyebaran yang jelas atau tidak membentuk pola-pola tertentu dan titik-titik tersebut menyebar di atas dan dibawah angka 0 pada sumbu Y, dengan demikian hal ini menunjukkan bahwa tidak terdapat gangguan heteroskedastisitas pada model regresi sehingga model regresi ini layak dipakai.

\section{Analisis Regresi Linier Sederhana}

Tabel 9. Regresi Sederhana Variabel Pelatihan

\section{Coefficients ${ }^{\mathbf{a}}$}

\begin{tabular}{|c|l|r|r|r|r|r|}
\hline \multicolumn{2}{|c|}{ Model } & \multicolumn{2}{c|}{$\begin{array}{c}\text { Unstandardized } \\
\text { Coefficients }\end{array}$} & $\begin{array}{c}\text { Standardized } \\
\text { Coefficients }\end{array}$ & \multirow{2}{*}{$\mathrm{t}$} & \multirow{2}{*}{ Sig. } \\
\cline { 3 - 5 } \multicolumn{2}{|c|}{} & \multicolumn{1}{|c|}{ B } & Std. Error & \multicolumn{1}{c|}{ Beta } & & \\
\hline \multirow{2}{*}{1} & (Constant) & 21.548 & 3,312 & & 6,507 & .000 \\
\cline { 2 - 5 } & Pelatihan (X1) & .457 & .087 & .518 & 5,276 & .000 \\
\hline
\end{tabular}

a. Dependent Variable: Kinerja Karyawan

Sumber : Data diolah (2020)

Berdasarkan hasil perhitungan regresi pada tabel di atas, maka dapat diperoleh persamaan regresi $\mathrm{Y}=21,548+0,457 \mathrm{X}_{1}$. Dari persamaan di atas maka dapat disimpulkan 
bahwa nilai konstanta sebesar 21,548 diartikan bahwa jika variabel Pelatihan $\left(\mathrm{X}_{1}\right)$ tidak ada maka telah terdapat nilai Kinerja karyawan (Y) sebesar 21,548 point. Nilai koefisien regresi Pelatihan $\left(\mathrm{X}_{1}\right)$ sebesar 0,457 diartikan apabila konstanta tetap dan tidak ada perubahan pada variabel Kompensasi $\left(\mathrm{X}_{2}\right)$, maka setiap perubahan 1 unit pada variabel Pelatihan $\left(\mathrm{X}_{1}\right)$ akan mengakibatkan terjadinya perubahan pada Kinerja karyawan (Y) sebesar 0,457 point.

Tabel 10. Regresi Sederhana Variabel Kompensasi Coefficients ${ }^{a}$

\begin{tabular}{|l|l|r|r|r|r|r|}
\hline \multirow{2}{*}{ Model } & \multicolumn{2}{|c|}{$\begin{array}{c}\text { Unstandardized } \\
\text { Coefficients }\end{array}$} & $\begin{array}{c}\text { Standardized } \\
\text { Coefficients }\end{array}$ & \multirow{2}{*}{$\mathrm{t}$} & \multirow{2}{*}{ Sig. } \\
\cline { 3 - 5 } & \multicolumn{1}{|c|}{ B } & Std. Error & \multicolumn{2}{|c|}{ Beta } & & \\
\hline \multirow{2}{*}{1} & (Constant) & 16,857 & 3,022 & 5,577 & 5,577 & .000 \\
\cline { 2 - 6 } & $\begin{array}{l}\text { Kompensasi } \\
\text { (X2) }\end{array}$ & .578 & .079 & .644 & 7,340 & .000 \\
\hline
\end{tabular}

a. Dependent Variable: Kinerja Karyawan

Sumber : Data diolah (2020)

Berdasarkan hasil perhitungan regresi pada tabel di atas, maka dapat diperoleh persamaan regresi $\mathrm{Y}=16,857+0,578 \mathrm{X}_{2}$. Dari persamaan di atas maka dapat disimpulkan bahwa nilai konstanta sebesar 16,857 diartikan bahwa jika variabel Kompensasi $\left(\mathrm{X}_{2}\right)$ tidak ada, maka telah terdapat nilai Kinerja karyawan (Y) sebesar 16,857 point. Nilai koefisien regresi Kompensasi $\left(\mathrm{X}_{2}\right)$ sebesar 0,578 diartikan apabila konstanta tetap dan tidak ada perubahan pada variabel Pelatihan $\left(\mathrm{X}_{1}\right)$, maka setiap perubahan 1 unit pada variabel Kompensasi $\left(\mathrm{X}_{2}\right)$ akan mengakibatkan terjadinya perubahan pada Kinerja karyawan (Y) sebesar 0,578 point.

\section{Analisis regresi linier berganda}

Tabel 11. Hasil analisis regresi linier berganda Coefficients ${ }^{\mathbf{a}}$

\begin{tabular}{|c|l|r|r|r|r|r|}
\hline \multicolumn{2}{|c|}{ Model } & \multicolumn{2}{|c|}{$\begin{array}{c}\text { Unstandardized } \\
\text { Coefficients }\end{array}$} & $\begin{array}{c}\text { Standardized } \\
\text { Coefficients }\end{array}$ & \multirow{2}{*}{$\mathrm{t}$} & \multirow{2}{*}{ Sig. } \\
\cline { 3 - 6 } \multicolumn{2}{|c|}{} & \multicolumn{1}{|c|}{ B } & Std. Error & \multicolumn{1}{c|}{ Beta } & & \\
\hline \multirow{3}{*}{1} & (Constant) & 9,866 & 3,341 & & 2,953 & .004 \\
\cline { 2 - 7 } & Pelatihan (X1) & .290 & .077 & 329. & 3,792 & .000 \\
\cline { 2 - 7 } & Kompensasi (X2) & .472 & .078 & 526. & 6,066 & .000 \\
\hline
\end{tabular}

a. Dependent Variable: Kinerja Karyawan

Sumber : Data diolah (2020)

Berdasarkan hasil analisis perhitungan regresi pada tabel di atas, maka dapat

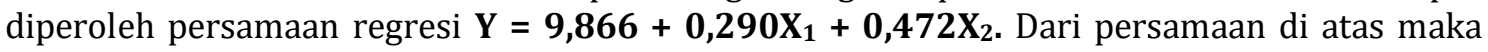
dapat disimpulkan sebagai berikut:

1) Nilai konstanta sebesar 9,866 diartikan bahwa jika variabel Pelatihan $\left(X_{1}\right)$ dan Kompensasi $\left(\mathrm{X}_{2}\right)$ tidak ada maka telah terdapat nilai Kinerja karyawan $(\mathrm{Y})$ sebesar 9,866 point.

2) Nilai Pelatihan (X1) 0,290 diartikan apabila konstanta tetap dan tidak ada perubahan pada variabel Kompensasi $\left(\mathrm{X}_{2}\right)$, maka setiap perubahan 1 unit pada variabel Pelatihan $\left(\mathrm{X}_{1}\right)$ akan mengakibatkan terjadinya perubahan pada Kinerja karyawan (Y) sebesar 0,290 point.

3) Nilai Kompensasi (X2) 0,472 diartikan apabila konstanta tetap dan tidak ada perubahan pada variabel Pelatihan $\left(\mathrm{X}_{1}\right)$, maka setiap perubahan 1 unit pada variabel Kompensasi $\left(\mathrm{X}_{2}\right)$ akan mengakibatkan terjadinya perubahan pada Kinerja karyawan $(\mathrm{Y})$ sebesar 0,472 point. 
Tabel 12. Hasil Koefisien Determinasi Model Summary

\begin{tabular}{|c|c|c|c|c|}
\hline Model & $\mathrm{R}$ & $\mathrm{R}$ Square & $\begin{array}{c}\text { Adjusted R } \\
\text { Square }\end{array}$ & $\begin{array}{c}\text { Std. Error of the } \\
\text { Estimate }\end{array}$ \\
\hline 1 & $.713^{\mathrm{a}}$ & .509 & .496 & 2.396 \\
\hline
\end{tabular}

a. Predictors: (Constant), Kompensasi, Pelatihan

b. Dependent Variable: Kinerja Karyawan

Sumber : Data diolah (2020)

Berdasarkan pada hasil pengujian pada tabel di atas, diperoleh nilai Koefisien determinasi sebesar 0,509 maka dapat disimpulkan bahwa variabel Pelatihan dan Kompensasi berpengaruh terhadap variabel Kinerja karyawan sebesar 50,9\% sedangkan sisanya sebesar $49,1 \%$ dipengaruhi oleh faktor lain yang tidak dilakukan penelitian seperti budaya organisasi, motivasi dan disiplin.

\section{Uji Hipotesis}

Pengujian hipotesis variabel Pelatihan $\left(\mathrm{X}_{1}\right)$ dan Kompensasi $\left(\mathrm{X}_{2}\right)$ terhadap Kinerja karyawan (Y) dilakukan dengan uji t (uji secara parsial). Dalam penelitian ini digunakan kriteria signifikansi $5 \%(0,05)$ dengan membandingkan $t$ hitung dengan $t$ tabel yaitu sebagai berikut:

1) Jika nilai $t_{\text {hitung }}<t_{\text {tabel }} \quad$ : berarti $\mathrm{H}_{01}$ diterima dan $\mathrm{Ha}_{1}$ ditolak

2) Jika nilai $t_{\text {hitung }}>t_{\text {tabel }} \quad$ : berarti $\mathrm{H}_{01}$ ditolak dan $\mathrm{Ha}_{1}$ diterima

Adapun untuk menentukan besarnya $t_{\text {tabel }}$ dicari dengan menggunakan rumus berikut ini:

$t_{\text {tabel }}=$ t $\alpha$.df (Taraf Alpha $\times$ Degree of Freedom)

$\alpha=$ tarif nya $5 \%$

Kriteria dikatakan signifikan jika nilai $t_{\text {hitung }}>t_{\text {tabel }}$ atau $\rho$ value $<$ Sig.0,05.

Tabel 13. Hasil Uji t Pelatihan

Coefficients ${ }^{\mathrm{a}}$

\begin{tabular}{|c|l|r|r|r|r|r|}
\hline \multicolumn{2}{|c|}{ Model } & \multicolumn{2}{|c|}{$\begin{array}{c}\text { Unstandardized } \\
\text { Coefficients }\end{array}$} & $\begin{array}{c}\text { Standardized } \\
\text { Coefficients }\end{array}$ & \multirow{2}{*}{$\mathrm{t}$} & \multirow{2}{*}{ Sig. } \\
\cline { 3 - 5 } \multicolumn{2}{|c|}{} & \multicolumn{1}{|c|}{ B } & Std. Error & \multicolumn{1}{c|}{ Beta } & & \\
\hline \multirow{2}{*}{1} & (Constant) & 21,548 & 3,312 & & 6,507 & .000 \\
\cline { 2 - 6 } & Pelatihan (X1) & .457 & .087 & .518 & 5,276 & .000 \\
\hline
\end{tabular}

a. Dependent Variable: Kinerja Karyawan

Sumber : Data diolah (2020)

Berdasarkan pada hasil pengujian pada tabel di atas diperoleh nilai $t_{\text {hitung }}>t_{\text {tabel }}$ atau $(5,276>1,992)$ Hal tersebut juga dipersedang dengan nilai $\rho$ value $<$ Sig.0,05 atau $(0,000$ $<0,05)$. Dengan demikian maka $\mathrm{H}_{01}$ ditolak dan $\mathrm{Ha}_{1}$ diterima, hal ini menunjukkan bahwa terdapat pengaruh yang signifikan secara parsial antara Pelatihan terhadap Kinerja karyawan pada PT G4s Security Service Jakarta.

Tabel 14. Hasil Uji t Kompensasi

Coefficients ${ }^{\mathbf{a}}$

\begin{tabular}{|l|l|r|r|r|r|r|}
\hline \multirow{2}{*}{\multicolumn{2}{|c|}{ Model }} & \multicolumn{2}{|c|}{$\begin{array}{c}\text { Unstandardized } \\
\text { Coefficients }\end{array}$} & $\begin{array}{c}\text { Standardized } \\
\text { Coefficients }\end{array}$ & \multirow{2}{*}{$\mathrm{t}$} & \multirow{2}{*}{ Sig. } \\
\cline { 3 - 5 } & \multicolumn{1}{|c|}{ B } & Std. Error & \multicolumn{1}{c|}{ Beta } & & \\
\hline \multirow{2}{*}{1} & (Constant) & 16,857 & 3,022 & & 5,577 & .000 \\
\cline { 2 - 7 } & Kompensasi (X2) & .578 & .079 & .644 & 7,340 & .000 \\
\hline
\end{tabular}

a. Dependent Variable: Kinerja Karyawan

Sumber : Data diolah (2020) 
Berdasarkan pada hasil pengujian pada tabel di atas diperoleh nilai $t_{\text {hitung }}>t_{\text {tabel }}$ atau $(7,340>1,992)$. Hal tersebut juga dipersedang dengan nilai $\rho$ value $<$ Sig. 0,05 atau $(0,000$ $<0,05)$. Dengan demikian maka $\mathrm{H}_{01}$ ditolak dan $\mathrm{Ha}_{2}$ diterima, hal ini menunjukkan bahwa terdapat pengaruh yang yang signifikan secara parsial antara Kompensasi terhadap Kinerja karyawan PT G4s Security Service Jakarta.

\section{Tabel 15. Hasil Uji F}

ANOVA ${ }^{a}$

\begin{tabular}{|c|c|c|c|c|c|c|}
\hline \multicolumn{2}{|c|}{ Model } & $\begin{array}{c}\text { Sum of } \\
\text { Squares }\end{array}$ & df & $\begin{array}{c}\text { Mean } \\
\text { Square }\end{array}$ & $\mathrm{F}$ & Sig. \\
\hline \multirow{3}{*}{1} & Regression & 446.224 & 2 & 223.112 & 38.874 & $.000^{\mathrm{b}}$ \\
\hline & Residual & 430.455 & 75 & 5.739 & & \\
\hline & Total & 876.679 & 77 & & & \\
\hline
\end{tabular}

a. Dependent Variable: Kinerja Karyawan

b. Predictors: (Constant), Kompensasi , Pelatihan

Sumber : Data diolah (2020)

Berdasarkan pada hasil pengujian pada tabel di atas diperoleh nilai $F_{\text {hitung }}>\mathrm{F}_{\text {tabel }}$ atau $(38,874>2,73)$, hal ini juga dipersedang dengan $\rho$ value $<$ Sig.0,05 atau $(0,000<0,05)$. Dengan demikian maka $\mathrm{H}_{01}$ ditolak dan $\mathrm{H}_{03}$ diterima, hal ini menunjukkan bahwa terdapat pengaruh yang signifikan secara simultan antara Pelatihan dan Kompensasi terhadap Kinerja karyawan pada PT G4s Security Service Jakarta.

\section{Kesimpulan}

Berdasarkan hasil penelitian, menunjukan bahwa Pelatihan (X1) dan Kompensasi (X2) berpengaruh posistif terhadap Kinerja Karyawan (Y) dengan diperoleh persamaan regresi $\mathrm{Y}=9,866+0,290 \mathrm{X} 1+0,472 \mathrm{X} 2$. Nilai koefisien korelasi atau tingkat pengaruh antar variabel bebas dengan dengan variabel terikat diperoleh nilai sebesar 0,713 artinya variabel Pelatihan dan Kompensasi mempunyai tingkat hubungan yang kuat terhadap Kinerja karyawan. Nilai koefisien determinasi atau kontribusi pengaruh secara simultan sebesar 0,509 atau sebesar $50,9 \%$ sedangkan sisanya sebesar $49,1 \%$ dipengaruhi oleh faktor lain. Uji hipotesis nilai $\mathrm{F}$ hitung $>\mathrm{F}$ tabel atau $(38,874>2,73)$, hal ini juga diperkuat dengan $\rho$ value $<$ Sig.0,05 atau $(0,000<0,05)$. Dengan demikian maka H01 ditolak dan Ha3 diterima, hal ini menunjukkan bahwa terdapat pengaruh yang signifikan secara simultan antara Pelatihan dan Kompensasi terhadap Kinerja karyawan pada PT G4s Security Service Jakarta.

\section{Daftar Pustaka}

Bolung, R.V, dkk. (2018). Pengaruh Pelatihan dan Kompensasi Terhadap Kinerja Pegawai pada BPMPD Provinsi Sulawesi Utara, Jurnal EMBA Unsrat, Vol 6 No 3, Hal:18381847. ISSN: 2303-1174.

Edison, dkk, ( 2016). Manajemen Sumber Daya Manusia. Bandung : Alfabeta.

Ghozali, I. (2017). Aplikasi Analisis Multivariate Dengan Program SPSS. Semarang: Badan Penerbit Universitas Diponegoro.

(2018). Model Persamaan Struktural Konsep dan Aplikasi Dengan Program AMOS 24. Semarang: Badan Penerbit Universitas Diponegoro.

Hamali, A,Y. (2016). Pemahaman manajemen sumberdaya mausia. Yogyakata: Center for Academic Publishing Servive

Handoko, T. Hani.(2014). Manajemen Personalia danSumberDaya Manusia. BPFE, Yogyakarta. 
Hasan, A. (2011). Teori dan Aplikasi Ekonomi Pembangunan Perspektif Islam Sebuah Studi Komparasi. Yogyakarta: Graha Ilmu.

Hasibuan S.P Malayu. (2014). Manajemen Sumber Daya Manusia. Jakarta: Bumi Aksara.

Hasibuan, Malayu S.P. (2016). Manajemen Sumber Daya Manusia. Edisi Revisi. PT Bumi Aksara : Jakarta.

: Jakarta.

(2017). Manajemen Sumber Daya Manusia. Edisi Revisi. PT Bumi Aksara

Istijanto. (2014). Riset Sumber Daya Manusia. Jakarta: PT Gramedia Pustaka Utama.

Kaswan M. M, (2011). Pelatihan dan Pengembangan untuk meningkatkan kinerja SDM. CV Alfabeta: Bandung.

Kasmir. (2016). Manajemen Sumber Daya Manusia. PT.Raja Grafindo Persada: Jakarta.

Lailatul, A dan Sunaryo, H. (2017). Pengaruh Pelatihan Kerja, Disiplin Kerja dan Pengawasan Kerja Terhadap Kinerja Karyawan Dinas Perindustrian dan Perdagangan Kabupaten Malang”. E-Jurnal Riset Manajemen Prodi Manajemen.

Lilis, S. (2014). Manajemen Sebuah Pengantar Sejarah, Tokoh, Teori dan Praktik. La Good Publishing: Bandung.

Mangkunegara, A.A. Anwar. (2011). Sumber Daya Manusia Perusahaan Cetakan Kedua Belas. Remaja Rosdakarya: Bandung.

(2016). Sumber Daya Manusia Perusahaan Cetakan Kedua Belas. Remaja Rosdakarya: Bandung.

Bandung : Remaja Rosdakarya.

(2017). Manajemen Sumber Daya Manusia. Perusahaan,

Marwansyah. (2016). Manajemen Sumber Daya Manusia Edisi Dua cetakan ke Empat. Alfabeta: Bandung.

Mora, M.T. (2018). Pengaruh Pelatihan dan Pengembangan Karier terhadap Kinerja Karyawan Pada Perusahaan Korporasi Jakrta. Jurnal Riset Manajemen dan Bisnis Universitas Bhayangkara Jakarta Raya. Vol 3 No 3, Oktober (2018) Hal: 342-352, Jurnal Jenius, ISSN: 2527-7502 e ISSN 2581-2165.

Nawawi, (2011). Manajemen Sumber Daya Manusia Untuk Bisnis yang Kompetitif. Gajah mada University Press : Yokyakarta.

Rini Astuti, Indah Sari, (2018). Pengaruh Pelatihan dan Kompensasi terhadap Kinerja Karyawan pada PT. Kemasindo Cepat Nusantara Medan. Jurnal STMIK Royal-AMIK Royal Universitas Sumatra Utara, vol 1 No 1, Hal: 461-464. 2018, ISSN: 2622-9986 e ISSN 2622-6510.

Rivai, V dkk, (2011). Performance Appraisal. PT. Raja Grafindo Persada: Jakarta

Rivai, V dan Mohd Basri, A.F. (2014). Manajemen Sumber Daya Manusia Untuk Perusahaan.. Edisi Ke 6 (enam) PT. Raja Grafindo Persada: Depok, 16959.

Rubera G. \& Eisingerich, A. B., (2010). Drivers of Brand Commitment: A Cross National. Journal of International Marketing.

Robert L.M . dan Jackson John, H (2012). Manajemen Sumber Daya Manusia. Edisi Pertama Salemba Empat, Jakarta.

Salinding, R, (2011). Analisis Pengaruh Pelatihan Terhadap Produktivitas Kerja Karyawan. Pada PT. Erajaya Swamsebada Cabang Makasar. Skripsi pada Universitas Hasanuddin Makasar : tidak diterbitkan. 
Sarwono, Jonathan. (2012). Metode Penelitian Kuantitatif dan Kualitatif. Yogyakarta: Graha Ilmu.

Shella, Ferri Y,S dkk. (2019). Pengaruh Pelatihan dan Disiplin Kerja terhadap Kinerja Karyawan pada PT Growth Asia Medan. Jurnal Manajemen Universitas Muhammadiyah Sumatra Utara, Vol 8 No 1, Hal: 1-10, ISSN: 2089-8529.

Sinambela L.P, (2016). Manajemen Sumber Daya Manusia. Jakarta: Penerbit PT. Bumi Aksara.

Singgih, S. (2015). SPSS20 Pengolahan Data Statistik di Era Informasi. Jakarta: PT. Alex Media Komputindo, Kelompok Gramedia.

Siregar. S. (2014). Metode penelitian kuantitatif dilengkapi dengan perbandingan perhitungan manual dan SPSS. Jakarta: Kencana.

Sudjana. (2014). Penilaian hasil proses belajar mengajar. Bandung: PT. Remaja Rosdakarya.

Sugiyono. (2008). Metode Penelitian Pendidikan Pendekatan Kuantitatif, Kualitatif dan R\&D", Alfabeta: Bandung.

. (2013). Metode Penelitian Pendidikan Pendekatan Kuantitatif, Kualitatif dan R\&D", Alfabeta: Bandung.

. (2016). Metode Penelitian Pendidikan Pendekatan Kuantitatif, Kualitatif dan R\&D", Alfabeta: Bandung.

(2017). Metode Penelitian Administrasi dilengkapi dengan Metode R \& D. Bandung: Alfabeta.

Sujarweni, V. Wiratna. (2014). Metode Penelitian: Lengkap, Praktis dan Mudah Dipahami. Yogyakarta: Pustaka Baru Press.

Suharsimi, A. (2015). Prosedur penelitian suatu pendekatan praktik. Jakarta : PT Rineka Cipta.

Sularmi, L. (2020). Pengaruh Pelatihan Dan Motivasi Kerja Terhadap Kinerja Pegawai pada Sektariat Dinas Perhubungan Provinsi DKI Jakarta. Jurnal Ekonomi Universsitas Pamulang, Vol 2 No 3, Juni (2020) , Hal: 496-504. ISSN :2622-8882 e ISSN 2622-9935.

Supangat, A. (2008). Statistik dalam Kajian Deskriptif, Infensi dan Paramatik. Jakarta : Kencana Prenada.

Sutrisno, E. (2010). Manajemen Sumber Daya Manusia. Kencana Pranada Media Group: Jakarta.

Suparno, E. W. (2012). Manajemen Pengembangan Sumber Daya Manusia. Yogyakarta: Pustaka Pelajar . Pustaka Pelajar.

Terry, G dan Rue, W. L. (2013). Aplikasi Analisis Multivariate Dengan Program IBM SPSS 21 Update PLS Regresi. Semarang: Badan Penerbit Universitas Diponegoro. . (2014). Dasar-dasar Manajemen. Jakarta: PT. Bumi Aksara.

Umar, (2011). Metode Penelitian Untuk Skripsi dan Tesis. Bisnis, Edisi 11. Jakarta: PT Raja Grafindo Persada.

Wibowo, F. (2018). Pengaruh Kompensasi dan Motivasi Terhadap Kinerja Karyawan (Studi Kasus Pada PT Indoraya Internasional, Yogyakarta), Jurnal Manajemen dan Bisnis Untirta, Vol 10 No 2, Hal: 173-187. ISSN: 1978-2241 e-ISSN 2541-1047 